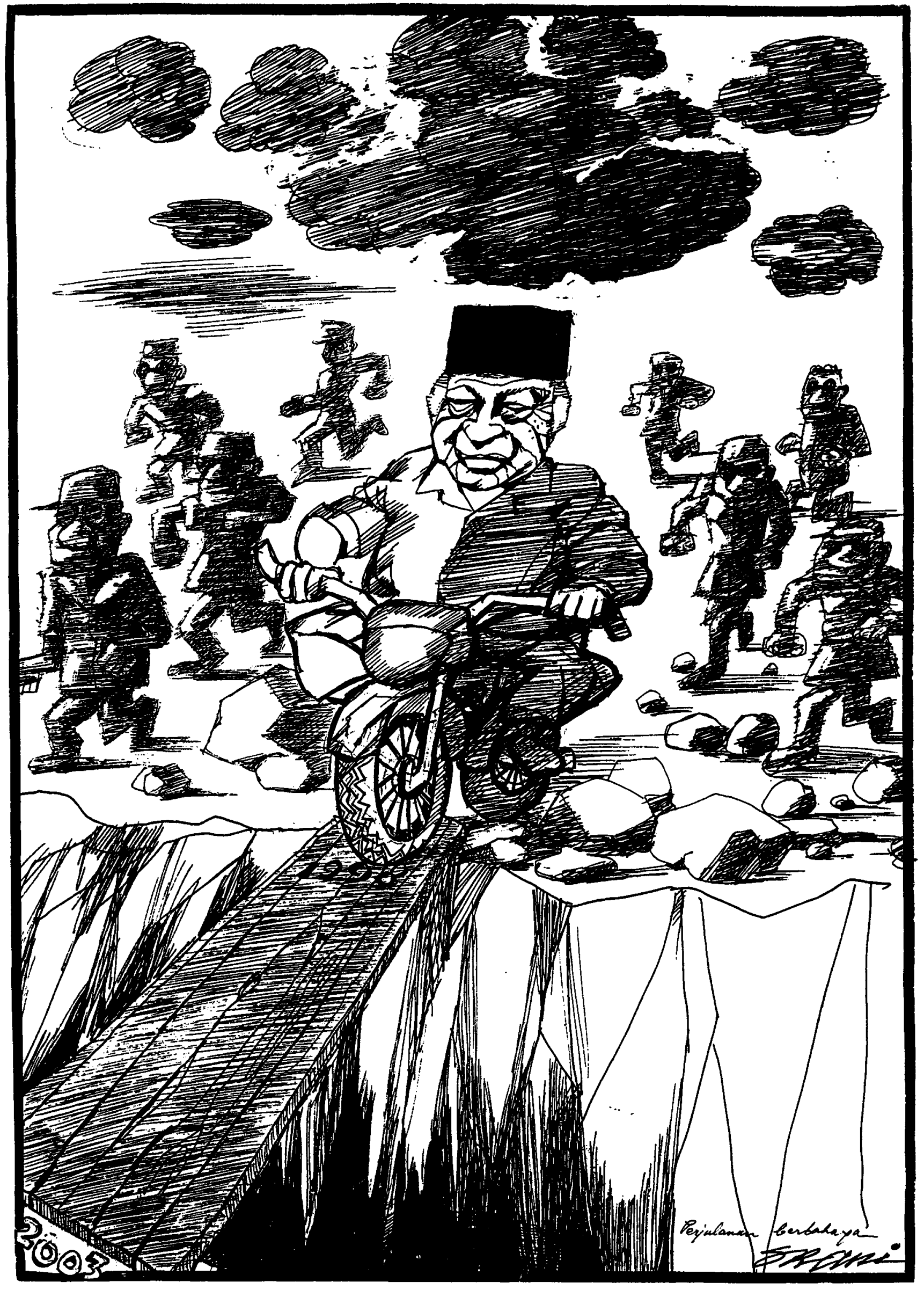









\section{PEMUDA PANCASILA: THE LAST LOYALIST FREE MEN OF SUHARTO'S ORDER?'}

\section{Loren Ryter}

"Since the Beginning Pemuda Pancasila has always Supported Reformasi carried out Constitutionally. The Coverage by the Print Media and the Electronic Media of Pemuda Pancasila's presence at the DPR RI on May 191998 is Mistaken and Without a Clear Source." So read the banner which hung in "strategic locations" in each of Jakarta's five boroughs within two days of Suharto's resignation. However, on May 21, two days before the banners went up and the evening after Suharto delivered his short statement of abdication, the confusion at Pemuda Pancasila [PP] HQ had yet to be so institutionalized. "There's been a bad misunderstanding," pleaded a shaken Alwi, in lieu of a salutation. He went on in defense of his organization, insisting it wasn't members of PP who brought the sign reading "The President of Indonesia Remains Haji M. Suharto" to the DPR [People's Representative Assembly], but rather it was FKPPI $^{2}$ that brought the sign. FKPPI had left their banner behind and some Pemuda Pancasila members just happened to pick it up. If they were caught before the cameras holding the banner, that was only because some of our members are under-educated and didn't think to read the sign first, explained Alwi, a Pemuda Pancasila member who once staffed the cigarette stand outside the youth group's HQ in front of the Tebet train station in South Jakarta.

\footnotetext{
1 This paper represents an overview of some main aspects of a dissertation project currently in progress. As it has been written while in Jakarta, I have not always been able to provide complete citations to relevant literature.

2 FKPPI (Communication Forum for Sons and Daughters of Retired ABRI) is headed by Bambang Trihatmodjo Suharto, a personal friend and hunting partner of Pemuda Pancasila Presidium Chief Yapto
} 
How is it that Pemuda Pancasila has been so routinely "misunderstood?" "Prodem" activists charge them with mobilizing masses for counter-demonstrations, raiding NGO offices and party headquarters, expediting land clearing on behalf of developers chiefly by pressuring land owners to sell at low prices, acting as private bodyguards for the Suharto family, and intimidating students and activists, especially in the months leading up to national elections-they have campaigned for Golkar (the political party approved by Suharto) since $1982 .{ }^{3}$ Various police commanders have periodically tried to bring in their most prominent leaders-Yapto Soerjosoemarno SH and Yorrys Raweyai-on gambling, assault, or gun charges. ${ }^{4}$ Office managers who have been hit up for large contributions tend to regard them, to quote one colorful comment, as "bandits, rotten, motherfuckers, gangsters, basically everything bad." 5 Society broadly is "under the impression" that they are an organization of preman

Soerjosoemarno and therefore PP's most likely point-man with the Cendana, Suharto's residence. ABRI: Angkatan Bersenjata Republik Indonesia, the Armed Forces of the Republic of Indonesia.

3 This article assumes a general familiarity with actions Pemuda Pancasila has participated in (or has been suspected of participating in) since the 1980s. Some worthy of mention are the disruptions of the PPP campaign at Lapangan Banteng during the 1982 elections; the burning of the LBH offices in Medan, attacks on the Garut Student-Youth Forum (FPPMG), SMID activists in Surabaya, and Megawati's PDI (Democratic Party of Indonesia) HQ during 1996; counter-demonstrations against Bishop Belo, Sri Bintang Pamungkas, and East Timorese refugees seeking asylum in Jakarta embassies during 1996. Rather than attempting to detail or demonstrate these cases (which would involve the notion of bukti, or proof, which both PP and the phenomenon of preman generally has contributed to problematizing), my intent is rather to discuss the conditions of the emergence of Pemuda Pancasila, both as available agents and as the usual suspects, in the context of youth during the Suharto period.

Prodem, short for pro-democracy, is a term frequently used by activists, especially in the 1990s, to refer to themselves. LBH, Lembaga Bantuan Hukum, is the Legal Aid Foundation. SMID, Solidaritas Mahasiswa Indonesia untuk Demokrasi, Indonesian Students' Solidarity for Democracy, is the People's Democratic Party's (PRD) student wing. PDI, Partai Demokrasi Indonesia, the Indonesian Democratic Party, and PPP, Partai Persatuan Pembangunan, the Unity Development Party, had been the sanctioned New Order political parties since 1973.

4 Yapto was detained for gun possession in 1981, and Yorrys has been held in relation to two gambling cases, one in 1994 and the other in 1998, as well as been accused of involvement in the fatal torture of the house boy of PP's secretary-general in 1994. None have resulted in a conviction. (The later case started when the houseboy, routinely taunted by PP members who called him a queer, kidnapped the secretary general's young son, who he had to baby-sit. After his arrest, PP members "borrowed" him from the police, tortured him, slicing off his ear, then returned him to the police. He later died of his wounds in detention.)

Yorrys, a half-Chinese, half-Irianese crocodile hunter and Phillips Petroleum manager from Serui, Irian Jaya, became involved in the Jakarta chapter of Pemuda Pancasila after Yapto took over in 1980. Before becoming head of the Jakarta chapter, he was entrusted with fundraising activities because of his connections with Chinese entrepreneurs and gambling. He is currently the "daily executive" chief of the national organization.

Yapto, an avid international hunter and adventure enthusiast, is the son of a Javanese General and a Dutch Jew. Yapto's background is further discussed below. Both Yapto and Yorrys are mixed breeds, which is significant since the prominence of Indos (Eurasians) in thuggery and gangsterism has a history that goes back to the colonial era. See Pramoedya Ananta Toer, House of Glass, trans. Max Lane (New York: Penguin Books, 1992).

5Interview with a Jalan Sudirman bank officer who complained that PP comes around periodically asking them to buy invitations to social functions at several million rupiah each. 
(street hoodlums) working as extortionists, debt-collectors, parking attendants, and nightclub security-when not outright violating the law. ${ }^{6}$

Yet Pemuda Pancasila devotes considerable effort to correcting this impression. Pemuda Pancasila claims to be a principled, disciplined, and militant organization of more than six million current members which vows to defend Pancasila and the 1945 Constitution, as it has done consistently since 1959, when other youth groups were still defending NASAKOM. ${ }^{7}$ Pemuda Pancasila is an independent organization not affiliated with any political party, and only happens to decide every five years through a regular congress to channel its members' aspirations to Golkar. It is the only youth organization brave enough to stand up for the youth of the informal sector. It "embraces" (merangkul) preman not for criminal purposes, but to raise their nationalist consciousness and return them to society. Some of its members do work as nightclub security and as parking attendants, but in their private capacity, not as members of the organization. ${ }^{8}$ If a member is caught in a criminal act, he is only an oknum, so the good name of the organization should not be besmirched. ${ }^{9}$ If he doesn't clearly possess a membership card, moreover, he is not necessarily even a member at all.

Through this combination of contradictory appearances, which show Pemuda Pancasila members visibly upholding the highest national ideals and appearing as the usual suspects of criminality, a prevailing logic of the Suharto period is clearly revealed. I wish to argue here that the emergence and rise to prominence of Pemuda Pancasila during the late Suharto era is a consequence of the need (and the effort since the early New Order) to transform a revolutionary nationalism of pemuda (youth) of the post-independence period into a nationalism expressed through loyalty to the (personalized) state itself, without, however, sacrificing the semangat (spirit) bestowed upon pemuda. ${ }^{10}$ As such, perjuangan (heroic struggle) had to take on a character that

6 Preman, in contemporary usage, is a street hoodlum, but the etymology and ambiguous connotations of the term will be discussed below.

${ }^{7}$ NASAKOM, Nationalism-Religion-Communism, the trilogy formulated by Soekarno circa 1961 to express his idea of national unity, was at the time resented by some for its inclusion of communism. After Suharto's rise to power, it became one of the justifications to tie Soekarno to the fate of the PKI, the Indonesian Communist Party.

8 In 1994, Yapto threatened to sue the weekly Sinar for calling Pemuda Pancasila an organization of debt collectors. The editors defended themselves on the grounds that they were quoting Jakarta Police Chief Major General Moch. Hindarto's remarks at a seminar on debt collectors. Prospek, September 3, 1994 and Jakarta-Jakarta, September 3-9, 1994.

9 Oknum, literally an "element" or an "individual" within a group, has come to mean any member of a group who acts outside of the mandate of the group, almost exclusively criminally. An approximate English equivalent might be "rogue." The term is used regularly in the press to refer to members of ABRI involved in robberies, shootings, backing gambling and prostitution, and the like. According to journalists, its use to refer to the misdeeds of $A B R I$ members has been an informal press regulation since at least the mid-1970s under the orders of Sudomo as commander of KOPKAMTIB (Command for the Restoration of Security and Order). In addition to oknum ABRI and oknum of youth organizations, references are occasionally made to oknum students, oknum journalists, and so forth. The term seems to be so reflexive that even "oknum preman" has appeared in print, reinforcing the idea that preman has come to acquire a quasi-official status.

${ }^{10} 1$ do not wish to emphasize a total transformation of pemuda values. Pemuda always carried this potential. Pemuda is used throughout not to refer to any specific age group, but in the expansive way it is used in Indonesia. See Benedict Anderson, Java in a Time of Revolution: Occupation and Resistance, 1944-1946 (Ithaca: Cornell University Press, 1972). Generally, it refers to members of an entire generation that has not 
rewarded private material gain, which ultimately turned youth into privateers, or preman. As perjuangan increasingly became identified with perebutan lahan (turf wars), the categories of pemuda and preman became intermeshed. The importance of the terms preman, pemuda, and oknum to an understanding of these changes, in light of the expansion of Pemuda Pancasila, will be explained below.

\section{Preman}

The significance of the epithet "preman" as applied to Pemuda Pancasila is best appreciated in reference to its sudden salience in the last years of the Suharto period. The often noted ambiguity between criminality and authority in the archipelago, whose lineage begins with the robber-king Ken Arok, and runs through the figure of the jago in colonial Java, found clear popular expression in the boom of premanism in the national press. Preman, in the sense of extortionists and hoodlums said to "prey on informal traders" and to "put society ill at-ease," began its phenomenal appearance on the national scene only after the fatal stabbing of First Lieutenant Budi Prasetyo at Blok M, Kebayoran in March 1995.11 That a mere preman had the insolence to slay an army officer in broad daylight was sensational, and the story took off, "premanism" appearing as the cover story of several major weeklies. Gatra illustrated "the War against Preman" with a skull-tattooed, muscle-bound arm gripping a serrated knife against an urban night-scape. Although local "rowdy youths" (pemuda berandalan), as they were described at the time of his murder, had also attacked and killed former BAIS Brigadier-General Tampubolon a year previously, the blame was only assigned explicitly to "preman" in retrospect, after the Prasetyo slaying, as part of the same perceived phenomenal upward swing in lawlessness and social unrest. ${ }^{12}$ Though the targets of preman subsequently tended to be described in the media as traders or

yet come of age or into official position. Thus the length of the Suharto era produced some rather aged pemuda.

11 Prasetyo, a Police Science student, was killed on March 6, 1995 near Melawai Plaza. Blok M traders say that Prasetyo was a womanizing drunkard who hit them up for too much money, and that local preman, in defense of the interests of the traders, approved his murder in advance, bringing in killers from outside. (Confidential interview.) Prasetyo's partner, Captain Arman Depari, who got away with stab wounds, told the press that the killers taunted him with, "Aw, you're just a captain. My dad's a general. Whatcha gonna do?" An Ambonese youth accused of the murder was shot in police custody three days later. See Gatra, March 18, 1995 and Forum Keadilan, March 30, 1995.

12 BAIS (Badan Intelijen Strategis) is ABRI's Strategic Intelligence Body. Tampubolon, killed on April 4, 1994, was a shady figure from the intelligence world, and a classmate of Eddie Nalapraya from the Bandung Infantry Center in 1963. [Eddie Nalapraya was one of the first commanders of President Suharto's private security detail, has held high staff positions in the Jakarta District Military Command during the 1970s, and has served as Vice-Governor of Jakarta in the 1980. See Tempo Weekly, Apa \& Siapa: sejumlah orang Indonesia 1985-86 (Jakarta: PT Pustaka Grafitipers, 1986). A long-time martial arts enthusiast, Eddie has served since 1994 as head of the Indonesian Pencak Silat Association (IPSI), with Prabowo Subianto as one of his functionaries.] Tampubolon's death did not generate the press sensation that Prasetyo's did a year later. The impression that his death was a politically-motivated hit was strengthened by the fact that coverage was limited. See Editor, April 21, 1994, pp. 19-30. One rumor circulating among journalists links the Tampubolon hit to the Eddy Tanzil corruption case, suggesting that Tampubolon had a list of names of generals and high officials receiving hush money or other pay-offs from Bapindo. The rumor is supported mostly by the timing of his death, as witnesses began to be called by the prosecutor around April 1994. 
society in general, it is significant that preman only earned a place in the national vocabulary through direct assaults on the authorities.

The press outcry prompted many to come to the defense of preman. As much as preman represent the underworld, they also stand for the underclass. Like the smalltime entrepreneurs they are accused of intimidating, preman are understood to originate from the least privileged sectors of society, to have been forced by circumstance to forgo an education, and to be among the swelling ranks of citydwellers who stand no chance of obtaining formal sector employment. Preman, having nothing to sell but their own muscles, have a right to be cut in on the take given the lack of economic alternatives. Extortion is, in effect, their line of work. ${ }^{13}$

More significant than the recurring debate about what to do about crime, however, was what preman implied about criminality and authority that a term like gali-gali did not. Gali-gali (gabungan anak-anak liar) were the "gangs of wild kids" finished off violently during the "Mysterious Shootings" (Petrus) operations of 1982-83.14 Though such an operation could never be complete, gali-gali could be said to have disappeared insofar as use of the term ceased after Petrus; thereafter to mention gali-gali became somewhat akin to pronouncing death. In recent years, preman has acquired a connotation comparable to that of gali-gali before Petrus, with two important differences. First, gali-gali was a collective phenomenon: the threat was that of roving gangs. A preman, though also implicitly drawing strength from his gang, could stand as a lone figure. Second, and more significantly, in contrast with the sense that gali-gali were understood to be unruly and unauthorized, the term preman has retained a quasiofficial ring.

Before the 1990s, preman more commonly referred to a policeman or a soldier who was not on duty, or to his civilian dress: berpakaian preman or baju preman, in his civvies. Often it also meant an undercover cop. It could even refer to something in private possession, not owned by the state, such as a private car (mobil preman). These were arguably the only meanings of preman in the national vocabulary at the beginning of the New Order, after which a slippage slowly began to occur. ${ }^{15}$ The productive play between these meanings contributed to the sensational response to the Prasetyo

\footnotetext{
13 Those who hold such views include reform lawyers and social researchers. Ruddy Agusyanto, for example, argues that preman is a profession, serving such socially necessary functions as debt collecting in a country where "the law cannot satisfactorily reach and manage the problem." Ruddy Agusyanto, "Preman adalah Profesi," Gatra, March 25, 1995, p. 20.

14 See also John Pemberton, On the Subject of "Java" (Ithaca: Cornell University Press, 1994); Justus M. van der Kroef, "'PETRUS': Patterns of Prophylactic Murder in Indonesia," Asian Suroey 25,7 (1985): 745-759.

15 Early in the New Order, preman was used to refer to undercover agents or off-duty soldiers even in contexts where their suspects would today be called preman. See for example the (subsequently banned) satire Langit Makin Mendung, in Sastra 6:8, 1968: "Si copet banyak menghajarnya ramai2. Si copet jatuh bangun minta ampun, meski hati geli menertawakan kebodohannya sendiri: hari naas, ia keliru njambret dompet kosong milik kopral sedang preman." [The pickpocket was pummeled by the crowd. The pickpocket rose and fell asking for mercy, but he had to laugh to himself at his own stupidity: bad luck, he made the mistake of snatching the empty wallet of a corporal in his civvies" (sedang preman).]

It should be noted here that perhaps the first appearance in the national press of "preman" in the contemporary sense came around June 1980, when the local government in Medan vowed to take firm action against "Si Preman," two months after Pemuda Pancasila clashed with another youth group, a story which also made the national press in April. See Tempo, April 19, 1980; Kompas, June 13, 1980.
} 
stabbing in 1995, since after all Prasetyo was killed while wearing baju preman, or plainclothes. Without making the connection explicit, Tiras ran its March 23 cover story under the headline "Preman and Preman." After the subsequent round-up of five hundred preman graduated from a two-week Express Skills Military Training Course, Tiras marveled at the transformation:

Who wouldn't fail to recognize the preman. Uniformed in green, crew-cut, and lined up in neat rows, they not only didn't look spooky [sangar]. At first glance, they even resembled honest-to-god soldiers [tentara beneran]. ${ }^{16}$

The ambiguity of the term is best understood by thinking of preman as a kind of privateer, an interpretation true to the colonial roots of the term vrijman, or free man. In fact, the lineages of preman can be understood in terms of its connotations in seventeenth-century Batavia and early twentieth-century Deli. To gain a perspective on preman in colonial Deli, it is useful first to briefly consider its folk etymology in North Sumatra today. By all accounts, the newly popularized meaning of preman as borderline-criminal marginal youths first circulated in post-colonial Medan, though some Batak today would like to see the term cleansed of its criminal associations. Sociologist Usman Pelly explained that the term preman "derives from youths who don't want to be bound to any dependencies, including a job or a contract." In a similar vein, Mangara Siahaan has written that preman in Medan were just youths whose "hobby it was to hang out, wear cool clothes, and look for a wife or girlfriend. If they find a wife, they relinquish their preman status." 17 To be preman is a matter of pride, they point out, because a vrijman was a freed plantation slave.

Early twentieth-century usage in Deli, however, indicates that a vrijman was not a freed slave, but rather a non-contract overseer or a coolie day-laborer, thus still in the employ of the company though not bound to it. One 1926 criminal case involving the torture of insubordinate coolies referred to one of the plantation overseers (mandor), who forced coolies to eat human and horse feces, as a vrijman. (The judge exonerated him, ruling he was only following orders of the chief mandor, a Japanese national, who was sentenced.) A Kompas article drawing on this case and other contemporary sources suggests that vrijman were involved in physical clashes between agents of plantation owners and Javanese and Chinese contract coolies. Although the article concludes that vrijman defended contract coolies against plantation thugs, the actual evidence quoted is ambiguous, stating only that they often "caused trouble."18

A vrijman of early seventeenth-century Batavia was similarly semi-employed. Vrijman meant someone "who is not in the service of the [Dutch] East India Company [VOC, Verenigde Oost-Indische Compangniel, but has permission to be in the Indies,

\footnotetext{
${ }^{16}$ See Cahyo Sukartiko, "Pembinaan Pasca-'Perang'," Tiras, April 6, 1995, p. 55. In this course, the preman were nominally taught skills in machinery, sewing, and automobile repair. They learned military discipline, and pledged to be good citizens in front of then Jakarta commander Wiranto.

17 Sinar, March 18, 1995 and March 25, 1995.

18 Kompas, February 6, 1994. The Poelau Mandi case, published in full in the daily Benih Timoer between October 19-30, 1926, is reprinted as an appendix in H. Mohammad Said, Koeli Kontrak Tempo Doeloe: Dengan Derita dan Kemarahannya (Medan: Harian Waspada, 1990), pp. 203-248. Note that although ungrammatical in Dutch, vrijman in Malay (like preman, a word used interchangeably with vrijman as early as the 1920s) is used as both singular and plural.
} 
and carries out trade for the sake of the [VOC]."19 In other words, he was a trader not listed on the company payrolls. A vrijman was literally a free agent, with one stipulation: that his agency was directed toward the requirements of VOC commerce. Not incidentally, in order to go about his business he required a permit from the company, to whose jurisdiction he therefore deferred. In Batavia, the vrijman was neither exactly a company man nor precisely not a company man.

The logic of this notion of freedom is nicely expressed by Pemuda Pancasila head Yapto Soerjosoemarno, who as the Jakarta head of an organization that first truly prospered in Medan, is well-placed to bridge the Batavia-Deli divide:

Preman means a free person, exactly free-man, I am one of these. A preman is a person who is free, not tied by any knot, free to determine his own life and death, as long as he fulfills the requirements and the laws of this country. But I am free to choose, to carry out the permitted or the not permitted, with all of its risks. For example, if you're a thief, you take the risks of being a thief, meaning if you're caught, you're finished. If you aren't caught, you're no thief right? Legally that's the way it is; we hold to the principle of the presumption of innocence. ${ }^{20}$

Yapto is bound by the very limitations he establishes, expressing a thematic ambivalence to the law. On the one hand, the law establishes the outer limits of freedom, as the trade permit did for the VOC vrijman, but with more complicated stipulations and a wider territorially reach. Yet the law is such a strict creature of orthodoxy that, ironically, one of its tenets (the presumption of innocence) provides the possibility of freedom from law itself. In a legal system where the proof (bukti) required to pronounce guilt is itself a commodity or an object easily wished into absence by those close to power such as Yapto, the presumption of innocence provides a gateway beyond the law. Freedom lies precisely in the ability to violate the law undemonstrably.

The ability of Pemuda Pancasila to accomplish this goal has rested on shedding their preman status by putting on the camouflaged uniforms of a youth organization. I mean something more than the charge that Pemuda Pancasila "hides behind the jacket of a youth organization." The nature of the jacket, the camouflage orange-and-black uniform, affects a resemblance to and expresses an affinity with those forces that would have the power to limit their freedom by calling to account their transgressions-transgressions which moreover are frequently of service to those very authorities. That these forces themselves always reserve the ability to transform themselves into preman by taking off their uniform only makes the distinction between preman and preman a matter of a thin, reversible skin. This reversibility, as I will argue, is what made Pemuda Pancasila both needed and ultimately outworn.

\section{Origin stories}

The roots of the symbiosis between the military, gangs, and formal youth organizations go back to the revolution. However, before the existence of a regular

\footnotetext{
19 Woordenboek der Nederlandsche Taal (Volume 23, VR-VUUSTER) (Leiden: Martinus Nijhoff, 1987).

20 Interview, Matra, January 1993.
} 
army, these entities were hardy discrete. During the revolution pemuda groups were or became irregular militias which fought in tandem with personnel trained by the Royal Dutch Army (the KNIL) and those mobilized in the twilight of the Japanese occupation. At a time of revolutionary flux and in the absence of a recognized legal system, the distinction between youth militias and roving gangs is difficult to draw, as Stoler has shown with the laskyar militias. Thus, to posit a relationship between gangs and nationalist youth during the revolution is anachronistic. Robert Cribb's study of the role of gangs in the Indonesian revolution, for example, assumes a prior distinction between younger nationalist politicians (read: pemuda) and rural gangsters, interested for their own reasons, whom the nationalists chose to recruit to achieve nobler ends. ${ }^{21}$ However, it is probably more accurate to imagine the distinction between the army, youth groups, and gangs emerging only after the consolidation of the Republic and the regularization of the army.

The appearance of Pemuda Pancasila can be seen in the context of efforts by former fighters (pejuang), and by the army itself, to find an appropriate political format during the party parliamentarianism in the 1950s, following the end of the revolution and the 1949 transfer of sovereignty to the Republic. Although there is reason to doubt that Pemuda Pancasila as reorganized by Yapto Soerjosoemarno beginning in 1980 bears significant resemblance in terms of personnel to the organization as it existed before 1965, there are institutional and a few personal threads that connect the organization across the Soekarno and Suharto regimes. (As explained below, a few of the founding Pemuda Pancasila leaders from North Sumatra were instrumental in recruiting Yapto in order to create a genuinely national organization.) The importance of the connection is also expressed in PP's sense of its own lineage. When recalling its founding history, Pemuda Pancasila's literature unfailingly notes, in the vaguest of terms, that Pemuda Pancasila was founded as an ounderbouw (subordinate wing) of the IPKI party (Ikatan Pendukung Kemerdekaan Indonesia, or League of the Supporters of Indonesian Independence). Pemuda Pancasila was born on October 28, 1959, the literature says, as part of the effort to "back-up" the Presidential Decree of July 5, 1959.22

Most likely the only accurate part of that statement is that Pemuda Pancasila was indeed born of General A. H. Nasution's IPKI, as a youth wing of the sort possessed by the other political parties. After his 1952 removal as Army Chief of Staff (KSAD), Nasution in 1954 formed IPKI in an effort to advance the army's agenda in a civilian political format. Members of IPKI were recruited from both active military men and former pejuang who had returned to civilian professions, as well as their families and friends. Through IPKI, Nasution was influential in pressing Soekarno to abandon the Constituent Assembly and return to the 1945 Constitution, which gave space for nonelected functional representatives (such as members of the army) to sit in parliament. IPKI stood against political parties and "-isms" in general and adopted Pancasila as a

21 Anderson, Java in a Time of Revolution; Robert Cribb, ed., The Indonesian Killings of 1965-1966: Studies from Java and Bali, vol. 1990, Monash Papers on Southeast Asia (Victoria: Monash University, 1990); Ann Laura Stoler, "Working the Revolution: Plantation Laborers and the People's Militia in North Sumatra," The Journal of Asian Studies 47,2 (1988).

22 The decree, which dissolved the Constituent Assembly and returned the country to the 1945 Constitution (UUD 45), marks the beginning of Guided Democracy. PP writes its founding story consistently if vaguely. See for example, Pancasila Abadi, June 1996, p. 25. Pancasila Abadi is PP's internal magazine, published irregularly in the late 1980 s and relatively regularly beginning in December 1990. 
symbol of what it conceived to be its neutral, even transcendent stance. ${ }^{23}$ It considered itself a movement rather than a party, though it competed in the 1955 elections with poor results-winning only four seats. In any case, it was army representatives, including Nasution in person, who successfully lobbied Soekarno into agreeing to the 1945 Constitution. By all accounts the founding of Pemuda Pancasila followed the Presidential decree.

The specific reasons for, and circumstances of, the formation of Pemuda Pancasila are not clear, and differing opinions on the matter reflect a complete split within IPKI over the organization's willingness to embrace Soekarno and his doctrine of ManipolUSDEK. ${ }^{24}$ At its third congress in Surabaya in July 1961, Ratu Aminah Hidayat, the wife of General Hidayat and a confessed admirer of Soekarno, became general chair of IPKI, occupying the IPKI offices at Menteng Raya. Her appointment was not accepted by Soegirman, IPKI's former chair, who regarded Ratu Hidayat as close to Moscow by virtue of her position on the Indonesian-Russian Peace Committee. Soegirman later retreated with his camp to his personal residence at Kebon Sirih. Soegirman's group had its own youth organization, Pemuda Patriotik (Patriotic Youth), but its chronology and relation to Pemuda Pancasila are matters of dispute.

All versions agree that Pemuda Pancasila was first inaugurated formally as an ounderbouw of IPKI at the Surabaya congress, but there is no consensus on how Pemuda Pancasila came into existence or on what became of Pemuda Patriotik. Members of Hidayat's group say that something called Pemuda Patriotik existed previously, then in 1959 dissolved itself into Pemuda Pancasila, whose existence in turn wasn't formalized by IPKI until the 1961 congress. ${ }^{25}$ The founders of Pemuda Patriotik say they only came together in 1960 at the request of Nasution, and that Pemuda Pancasila never existed before they agreed to the name change at the Surabaya congress. ${ }^{26}$ After these Soegirman supporters realized that they had been trumped by Soekarno and Hidayat, Pemuda Patriotik continued to maintain a separate existence, never in practice fusing with Pemuda Pancasila under the orbit of Hidayat's

${ }^{23}$ David Bourchier, "Lineages of Organicist Political Thought in Indonesia" (PhD dissertation, Department of Politics, Monash University, 1996), p. 122. It is beyond the scope of this article to detail the social and ideological underpinnings of IPKI, though its efforts were clearly important in the rise of a corporatist state. On Nasution and IPKI, see Bourchier, "Lineages of Organicist Political Thought in Indonesia," pp. 119-130. On Nasution and the transition to Guided Democracy, see Daniel S. Lev, The Transition to Guided Democracy: Indonesian Politics, 1957-1959 (Ithaca: Cornell Southeast Asia Program, 1966). In its own literature, IPKI tended to hyphenate its abbreviation, perhaps in an effort to separate itself from the PKI.

${ }^{24}$ Soekarno's Political Manifesto of August 17, 1959 was Soekarno's official explanation of the July 5, 1959 decree and represented an attempt to fashion an interpretation of the 1945 Constitution in his own (sloganistic) terms, abbreviated as USDEK: the 1945 Constitution, Indonesian Socialism, Guided Democracy, Guided Economy, and the Indonesian Character.

25 Based on several interviews with IPKI members from the period, including Ponke Princen, M. Noeh, J. L. L. Taulu, and Victor S., and on a document prepared by M. Supangat entitled "Hubungan Ideologis dan Historis IP-KI dengan Ormas Karyawan Pancasila" prepared in June 1998 at the request of M. Noeh.

26 The reason given at the congress for the name change was that the name "Patriotik" smelled of communism. Interview with J. L. L. Taulu and Victor S., August 24, 1998. 
IPKI until after September 1965, when General Suharto's spin on G30S made the PKI available as the new common national enemy. ${ }^{27}$

For an organization that today boasts of its militant anti-communism, it is ironic that today's Pemuda Pancasila has adopted the history as recalled by Hidayat's camp, illustrating PP's tradition first and foremost as presidential loyalists (and like the New Order itself, with roots in Guided Democracy). It also reflects PP's concern with form. Indeed, its founding day appears to have been chosen retrospectively mostly for its symbolic significance as the anniversary of the 1928 Youth Pledge. Spego Goni, who calls himself the founder of PP and was chairman of Hidayat's Pemuda Pancasila from 1961, writes "[October 28 1959] is the date that I gave to Mr. Yapto Soerjosoemarno SH, in Menado, as the birth date of Pemuda Pancasila as has now become the historical 'birthday' of Pemuda Pancasila." His activities on that day, he admits, consisted of writing his name as a representative of "Pemuda Pancasila" (rather than as secretary of Jakarta's IPKI branch, which he then was) in a guest book at a ceremony celebrating the anniversary of the Youth Pledge. At the time, there was no organization, but he soon prepared a letterhead and a stamp. ${ }^{28}$

Oddly enough, the impulse to create a militant, mass-based youth organization arose from a beauty contest. It was also a demonstration of loyalty. At the end of December 1961, in the midst of Soekarno's call for mass mobilization to "liberate" West Irian from the Dutch, Spego Goni was busy organizing the first Miss Indonesia contest. After Soekarno publicly denounced the contest on the grounds that it was not in keeping with the national character, Pemuda Rakyat (People's Youth, the youth wing of the PKI) members throughout Jakarta tore down publicity posters and banners. Crushed by the Great Leader of the Revolution's rejection, Spego "wanted to prove that his ideas weren't limited to the Catwalk, but also [could be applied] on the battlefield." 29 Spego then put forward the idea of forming Pemuda Pancasila combatready troops and offering to send them to West Irian. On January 4, 1962, he led a group to the National Front $H Q$, where they presented a letter announcing their support of TRIKORA ${ }^{30}$ and the existence of one thousand trained members and forty thousand other members standing by throughout Indonesia, awaiting the command to be sent to the front lines. The problem was that PP didn't have a complete secretariat, let alone a mass base. To make the bluff credible, Spego instructed a fellow Menadonese, Phill Sulu, whom he had just made a secretary, to come up with a list of ten thousand names. As one of several thousand former Permesta rebels who were at the time being re-indoctrinated in East and Central Java, Sulu had access to the rolls of

27 G30S-short for the September 30th Movement-is used as a shorthand reference to the beginning of the regime transition and does not imply any particular claim about instigators.

${ }^{28}$ See Spego Goni, in Sejarah Singkat Lahimya "Pemuda Pancasila," ed. YAPPKI (Jakarta: Yayasan Amal Pembangunan Pejuang Kemerdekaan Indonesia, 1993), pp. 40-42. The book is not distributed -or authorized-by Pemuda Pancasila's central board of directors.

29 Phill M. Sulu in Sejarah Singkat Lahimya "Pemuda Pancasila," pp. 28-37. According to Princen, another IPKI figure who worked with Spego on the beauty contest, Spego was not much of a politician, "but knew what people liked." Conversation with Princen, August 20, 1998.

30 TRIKORA (Tri Komando Rakyat) was the instruction announced by Soekarno on December 19, 1961, calling for crushing the Dutch puppet state of Papua, raising the Indonesian flag in West Irian, and preparing for popular mobilization of volunteers to be sent to Irian. 
Permesta battalions being rehabilitated. ${ }^{31}$ These names he copied directly into the fictive ranks of Pemuda Pancasila, adding some names from Jakarta supplied by Spego. This bluff resembles a tactic that PP eventually adopted during the New Order, when, in order to make itself visible to Golkar, it sent busloads of members along the campaign trail in advance to "greet" campaigners like Harmoko as they rolled into towns where PP as yet had no members. ${ }^{32}$

Pemuda Patriotik, however, went about building a mass base in Jakarta by recruiting urban marginals for construction work, a method later to become standard for PP. Pemuda Patriotik realized that pemuda were necessary to create a mass base for IPKI, and if nothing else they constituted a good work force able to perform tasks such as putting up campaign posters. In order to "accumulate masses" (menghimpun massa) the organizers gathered "vagrants and the unemployed" from the Pasar Senen area, and trucked them to the Senayan sports complex to perform "service work" under the IPKI flag. IPKI had been given the project (dapat jatah) for the development of Senayan because there were a number of IPKI ministers in Soekarno's Working Cabinets, including Minister of Trade Arifin Harahap. The new recruits were given a wage, and thereafter became members of Pemuda Patriotik. ${ }^{33}$

Yet in the early 1960s, Pemuda Pancasila took on its character mostly outside Jakarta, particularly in Medan. Sometime around the time of the Surabaya IPKI congress, a boxer named Effendi Nasution, known as Effendi Keling as well as "the Lion of Sumatra," was recruited as Pemuda Pancasila chair. ${ }^{34} \mathrm{He}$ was acquainted with the North Sumatra IPKI chief because he controlled black market sales of movie tickets at the Medan Theater, located directly across the street from the IPKI offices. Before he joined Pemuda Pancasila, Effendi already led his own youth organization, P2KM (Persatuan Pemuda Kota Medan, Medan City Youth Union), which may have set a precedent in that it was a formal organization not attached to any party or political organization and appeared mainly as a way to build a personal power base for the charismatic figure of Effendi himself. P2KM, like PP-Medan which it became, was primarily an enterprise employing street youth in extortion and private security as night guards, particularly for ethnic Chinese. In 1967, Effendi became a parliamentary delegate representing the youth element of IPKI, and brought a number of his boys (anak buah) with him to Jakarta. ${ }^{35}$ Although he returned after a year, many of these boys stayed behind. He remained a mobilizer of Pemuda Pancasila until his death in 1997 and was the main point man for Jakarta.

After September 1965, Pemuda Pancasila in Medan and Aceh were particularly active in slaughtering suspected communists, arguably taking the leading role in North Sumatra as Pemuda Ansor of NU (Nadhatul Ulama) did in parts of Java and PNI

31 Permesta, the so-called Semesta Struggle, was an armed movement based in Sulawesi put down in 1958 by the central government. See Barbara S. Harvey, Permesta: Half a Rebellion, (Ithaca: Cornell Modern Indonesia Project, 1977).

32 Interview with Adil Meliala, July 24, 1998.

33 Interview with J. L. L. Taulu and Victor S.

${ }^{34}$ Effendi was not a keling (of Indian descent), but a Mandailing Batak. There is a common agreement that he was called Effendi Keling because he was "black," as Keling and black are thought to be synonymous by most residents of Medan who are not ethnic Indian.

35 J. L. L. Taulu and Victor S., cited above. 
(Partai Nasionalis Indonesia, Indonesian Nationalist Party) did in Bali. ${ }^{36}$ Having sliced off the ears of communists is still a matter of pride for PP elders from North Sumatra and Aceh. (Effendi himself is rumored to have presented Soekarno, to the president's displeasure, with a bundle of dried ears of ethnic Chinese he obtained during a largescale anti-Chinese riot he and his boys provoked in December 1965.) Their targets included the PKI youth wing Pemuda Rakyat but also organizations considered close to the PKI, including the Indonesian Farmers' Front (BTI) and Baperki, the largely Indonesian Chinese citizenship association. PP's conflict with Pemuda Rakyat started before G30S, as early as 1964, when acting as security for HMI and SOKSI functions, Pemuda Rakyat leveled at them such insults as "bandits, devils, and urban bourgeois." 37 Pemuda Pancasila literature boasts that PP in Medan "took revenge" on the BTI for killing an army lieutenant working as private security at the Bandar Betsy plantation in May 1965. The literature emphasizes PP's bravery in the face of the BTI, but gives no specifics about the lieutenant's death (he was obstructing local farmers from planting on property claimed by the company) nor about Pemuda Pancasila's response (apparently there was no actual counter-attack on the BTI until army ascendancy after G30S made it safe or encouraged them to act). Early in November 1965, after Pemuda Pancasila attacked the village of Kampung Kolam, said to be a BTI base where PKI refugees were taking shelter, the bodies of two members of PP were discovered at a spot in the middle of a rice field where an obelisk monument has since been erected in their memory. Surviving residents say they know nothing of the bodies, only that the night of the attack, all the men were taken in trucks to the regional military command post for a week-long interrogation, and for four months thereafter people from Medan in "preman" clothes, periodically yelling "Pancasila!," terrorized them, stealing all their clothing and chickens.

Pemuda Pancasila in Jakarta, like a number of other youth groups and gangs, were more interested in property theft than corporal dismemberment. Although PP in Jakarta was relatively small by the standards of the capital, numbering at most five thousand, they took part in raids on PKI and Baperki properties, including the CC PKI's Peace Committee office on Jalan Raden Saleh, where they made off with typewriters and stencil machines. Later this property was used as offices for General Ali Moertopo's "special operations" intelligence unit, Opsus. When they could, they would hang onto control of the properties, as they did with the Baperki office on Jalan Wahid Hashim. This became the Mapancas (IPKI's Pancasila Students) HQ for several years before being sold by a Mapancas chair for private gain, the eventual fate of many of the properties seized at the time. Although PP in Jakarta asked for and were given

\footnotetext{
36 On the part youth groups played in the killings, see Cribb, The Indonesian Killings of 1965-1966; Harold Crouch, The Army and Politics in Indonesia (Ithaca: Cornell University Press, 1988), chapter 5; Geoffrey Robinson, The Dark Side of Paradise: Political Violence in Bali (Ithaca: Cornell University Press, 1995). Note that despite the well-documented role of the party youth wings in the killings, it is precisely not as rampaging mass-murderers that "pemuda" has become established during the New Order.

37 Bonar Harahap, 1992, "Persepsi Pemuda Pancasila Terhadap Perjuangan Orde Baru," Skripsi, Fakultas Ilmu Sosial \& Ilmu Politik, Universitas, 17 Agustus, 1945, Jakarta, pp. 32-35. Activists from HMI, the Islamic Students' Association, later tended to become prominent figures in the pro-New Order Student Action Commando (KAMI), and were subsequently rewarded with high positions. SOKSI (Sentral Organisasi Karyawan Sosialis Indonesia) was a "workers' union" formed by the army to counter the PKIaffiliated labor union, SOBSI (Sentral Organisasi Buruh Seluruh Indonesia). SOKSI later became one the three founding organizations of Golkar.
} 
thirty or forty short-term licensed pistols by the army, they never had to use them, as all the "communists" had already fled to the regions by the time they showed up at their homes in the "fence of legs" encirclement campaigns in the kampungs. ${ }^{38}$

After these youth actions at the advent of the New Order, Pemuda Pancasila as a national organization entered a period of quiescence. PP's literature invariably describes the entire 1970s, before the entry of Yapto as chairman, as a period when the organization was "fast asleep." However, Pemuda Pancasila continued to maintain a visible presence in North Sumatra. The difference between Medan and Jakarta can be attributed mostly to their respective patterns of recruitment and access to resources. Pemuda Pancasila in Medan deliberately recruited a majority of the city's preman, and into the 1970s they continued to control virtually all of Medan's bioskop (movie theaters), and later expanded into entertainment complexes and small-scale gambling as a source of revenue. The license granted to their members during 1965-66 (PP members were allowed to go anywhere and defy night curfews in the hunt for suspected communists) won them substantial political clout and attracted members, many of whom, especially members of the PNI's youth wing, Pemuda Marhaen, joined for protection. ${ }^{39}$

Pemuda Pancasila in Jakarta, on the other hand, had far fewer members, particularly relative to other youth organizations. Members of Pemuda Pancasila tended to be the children or relatives of IPKI party members and may have thus been more oriented to elite party politics, the "excesses" of 1965-66 notwithstanding. However, the claim that Jakarta's PP was "fast asleep" is not entirely accurate. It seems that during this period of quiescence in the 1970s, members of Pemuda Pancasila were active and instrumental in cleaning out the Soekarno loyalists in the PDI when, during the 1973 party fusion, IPKI and the PNI were both made to join PDI. With IPKI and the PNI now fused into a single party, Marhaenist elements (supporters of Soekarno's populist ideology in the PNI) could be easily undermined from within. Although PP declared itself independent from IPKI at the time of the party fusion, in practice many of its members continued to provoke and discredit Marhaenists at party and youth wing meetings and congresses. ${ }^{40}$

\section{The Establishment of the Historic Role of Pemuda}

The vigorous participation of youth groups in the army's effort to eradicate its enemies, later to be enshrined as an "historic partnership," both cemented a nationalist logic of the "historic role of pemuda" and presented certain intractable problems during the consolidation of the New Order. The pemuda had already long been hailed as the driving force of Indonesian nationalism. Having been considered as the authors of the nascent notion of "Indonesia" by 1928 (as a result of the "Youth Pledge") and also as shapers of the character of the nationalist revolution against the Dutch (1945-49),

\footnotetext{
38 Interview with ML Tobing, August 13, 1998.

39 PNI, the Indonesian Nationalist Party, was briefly banned in North Sumatra by General Sarwo Edhie after he became Bukit Barisan District Military Commander in 1967. According to one Pemuda Marhaen activist, virtually all the Marhaenist Youths in his kampung joined Pemuda Pancasila.

40 Interview, Endi Syafiruddin, August 14, 1998.
} 
pemuda were now available to be credited with ushering in the New Order regime (1965-66). ${ }^{41}$ On the one hand, the role of pemuda provided an ideal way to legitimate the new regime within the teleology of the nationalist struggle. On the other hand, too much emphasis on the role of pemuda left open a possibility of an undesirable repeat performance. If youth had been designated as the embodiment of radical change, and change was now to be stalled in favor of stability and regime consolidation, the question became how to contain the excess of youth. Having established the historic role of pemuda, the task for the New Order, somewhat ironically, was to establish youth's role as merely historic.

This entailed refashioning of the meaning of pemuda itself, from a term describing those in the vanguard of change to a term describing something like the bodyguard of "change." "Change" was presented as ongoing (the "renewal" of the New Order would be perpetual) but the word actually referred to a static and increasingly distant moment: the replacement of Soekarno and his regime. Thus by the mid 1970s, three "historic events" - the Youth Pledge in 1928, the Independence Proclamation in 1945, and the "coalition" of the students and the army which led to the establishment of the New Order-began to appear not as examples which represented something permanently and irrepressibly characteristic of youth, but instead as the defining events which, through their routinized recollection, pronounced any future outbursts of youthful energy to be superfluous. At the culmination of a progression of "radical" (and clearly delineated) changes, the youth appeared to have fulfilled their third and final obligation in their participation with the army in the establishment of the New Order regime.

This shift was accomplished through a realignment of the term pemuda itself, relegating it both institutionally and discursively to a position of relative stability (and backward signification) while producing different designations to delimit the young. University students, mahasiswa, were increasingly regarded as a separate category from pemuda, and were themselves eventually cut off from active politics with the "campus normalization" policy of 1978. Meanwhile, young people as demographic and social beings found description in the newly-popularized term remaja—or teens-and were thus transformed from political actors into passive consumers. ${ }^{42}$ This left "pemuda" to be reserved as a term for historical actors, as well as youths willing to wear the uniform jackets of the New Order, who could conceive of themselves as living agents of history within the bounds of modernist development. Institutionally, this meant cooperating with an expanding bureaucracy of Youth and Sports and participating within the framework of KNPI, the Indonesian National Youth Council, created in 1973 under circumstances described below.

These shifts did not happen all at once and were reflected on the streets of Jakarta by the changing dynamics of activism and youth gangs during the first few years of

\footnotetext{
41 Anderson, Java in a Time of Revolution; Yoazr Anwar, Angkatan 66: Sebuah Catatan Harian Mahasiswa (Jakarta: Sinar Harapan, 1980); B. Sularto, Dari Kongres Pemuda Indonesia Pertama ke Sumpah Pemuda (Jakarta: Balai Pustaka, 1986).

42 Although important to this discussion, detailing these linguistic changes is beyond the scope of this article. One might note that taking refuge in "remaja" may also have been a way for some young people to bow out of the political demands of pemuda. For more on remaja, see James T. Siegel, Solo in the New Order: Language and Hierarchy in an Indonesian City (Princeton: Princeton University Press, 1986).
} 
the Suharto period. The most notorious "gangs" were those centered in the various military complexes around Jakarta. Thus, Berlan, a complex of enlisted men and lower officers in the Matraman area which in KNIL times was known as Berenlaan, gave birth to the Bearland Boys. Similarly, sons of the middle officers housed at the asrama on Jalan Siliwangi near Lapangan Banteng went by the name Siliwangi Boys Club. Several figures leading the reincarnation of Pemuda Pancasila in 1980, including Yapto, came out of the Siliwangi Boys. Their advantage over other gangs was their "facilities": they could always borrow their fathers' guns. ${ }^{43}$ In the Kebayoran area, the Radio Dalam Club (RDC) was based in the navy complex. The elite areas of Menteng and Kebayoran Baru also had their own gangs, notably Legos (the "Nudge Rocker Boys") of Blok M.44 Since the later 1950s, Menteng especially had known vaguely defined "crossboys," admirers of James Dean and Elvis Presley who liked to stay up all night and hold parties which the authorities considered to violate Indonesian values or even to be influenced by foreign intervention. ${ }^{45}$ Various other groups were based on regional affiliation, such as Ams, Ambonese housed in the old colonial STOVIA medical school building, Pamors (Padang-Manado Organization), and Sartana, mainly Menadonese who controlled the Sarinah-Tanah Abang retail districts. These latter groups were not necessarily "ethnically" based, because many of the leading figures were the sons of ABRI officers stationed in the "regions," who consequently grew up identifying with them. ${ }^{46}$

Many of these local gangs became part of the mass of protesters who, in 1965-66, became collectively known as KAMI and KAPPI. ${ }^{47}$ Demonstrating was a "hobby," and a lucrative one too as it justified the collection of "struggle funds" (dana perjuangan) from the Chinese, a tradition resurrected from the Revolution in the new context. After the years of demonstrations of 1965 and 1966 (which involved seizing properties and chasing suspected communists and other enemies) had waned, mass demobilization meant returning to respective neighborhood gangs. "With the end of the struggle at that time, all activities which channeled the spirit of teens and youth began to lose focus," writes Legos member Leo Tomasoa about his own gang.

\footnotetext{
43 Interview with Tagor Lumbanraja, Secretary General of Pemuda Pancasila 1981-1991 and once a Siliwangi Boys member, August 18, 1998. Though most of their fathers were colonels, Soerjosoemarno, Yapto's father, was a general. The Siliwangi complex was leveled in 1984 on the orders of Try Sutrisno, for the purpose of getting rid of the gangs.

44 Members of Legos (Lelaki Goyang Senggol) openly entered politics. Its members included Mangara Siahaan, currently a leader of Megawati's PDI, and Leo Tomasoa, who was to become one of Ali Moertopo's agitators circa Malari through his position in the "Group of 10" at University of Indonesia, which also included erstwhile KNPI activists cum Golkar leaders Aulia Rahman and Freddy Latumahina. See Sinar, March 18, 1995, and Heru Cahyono, Peranan Ulama Dalam Golkar 1971-1980: Dari Pemilu Sampai Malari (Jakarta: Pustaka Sinar Harapan, 1992), p. 161. The nominally anti-Japanese and anti-foreign capital rioting in Jakarta in January 1974, subsequently called the Fifteenth of January Disaster, or Malari, has since been commonly interpreted as an elite dispute between Ali Moertopo and General Soemitro. The Group of 10 was a core of University of Indonesia students cultivated by Ali Moertopo.

45 One police speech given on the problem quoted a private driver's opinion that cross-boys are "enemies of the state." This speech questioned the perception that cross-boys were mainly an elite phenomenon. A. Soebroto Soedewo, "Cross-Boys Sebagai Masaalah Sosial," Bhayangkara 9,2 (1959): 6.

${ }^{46}$ Confidential interview, July 18, 1998.

${ }^{47}$ Kesatuan Aksi Mahasiswa Indonesia and Kesatuan Aksi Pemuda Pelajar Indonesia.
} 
60 Loren Ryter

The demonstrators returned to their original function, where high school students went back to the school bench, university students went back to campus, but not a few of them continued their habit of hanging out and goofing off which often meant hassling people who happened to pass by, asking for money from them, and picking fights. 48

Thus these demobilized youths of the early New Order presented a problem to the state similar to that presented by the pejuang who had not been "regularized" after the revolution, save that for the most part regularization meant less the provision of uniforms or the granting of ranks, and more often meant the creation of additional opportunities to provide certain services, and in some cases involved integrating them into the bureaucracy or parliament.

I want to highlight a single turning point which was to separate "new-style" pemuda from the lingering rabble-rousing student demonstrators of 1965-66 and set the stage both for the institutionalization of youth and for the various and varyingly successful efforts to integrate gangs into the state apparatus which culminated in Petrus (1982-83) and thereafter the rise of Pemuda Pancasila. I refer to the "resolution" of student opposition to Tien Suharto's fantasy "Beautiful Indonesia"-in-Miniature Park project at the end of 1971. In the years before the "historic generation" of 1966 succeeded in establishing itself as the "final generation," some youth and student groups continued to press for change in their characteristic manner, failing to realize that their mission was already considered to be accomplished. Nor did they heed the large no-trespassing sign on Jalan Cendana: to directly challenge the interests of the first family was strictly off-limits. Criticism of the proposed land evictions required for the construction of the Mini Park and of wasteful extravagance only made Tien "all the more perfect in tackling the issue." Growing protests prompted the president to vow: "Quite frankly, I'll deal with them! No matter who they are! Anyone who refuses to understand this warning, frankly I'll deal with them!"49 In a book published in 1971 on the history of the youth movement, it was still possible to include youth protests against Tien's project as a new element in the historical line of Budi Oetomo, the Youth Pledge, the Revolution, and the ousting of Soekarno. This error was, in the spirit of the president's warning, almost immediately to be erased. ${ }^{50}$

Tien's "perfection" in tackling the problem found expression in the assault on demonstrators by members of the Berlan gang. On December 23, 1971 a group of longhaired boys confronted a number of youth demonstrators at the Miniature Project secretariat, which shared offices with Tien's Our Hope Foundation. When challenged, one said "Wah, here's a crossboy wants to make trouble, nih," pulling out a machete. Shots were fired, glass was broken, two demonstrators were stabbed and one shot in the thigh with a .45. "At the time, we were the long-hairs," recalled Asmara Nababan,

\footnotetext{
48 See Leonard Tomasoa, "Kepemimpinan Dalam Gang-X" (Suatu Studi Terhadap Kehidupan Gang Di Daerah Kebayoran Baru), Skripsi, Fakultas Imu-Ilmyu Sosial, University of Indonesia, Jakarta, p. 25. See also Sinar, March 18, 1995.

49 Tien Suharto quoted in Kompas, December 16, 1971. On Taman Mini "Indonesia Indah," see John Pemberton, On the Subject of "Java" (Ithaca: Cornell University Press, 1994), pp. 152-161. Suharto quoted, page 153, originally translated by Benedict Anderson, "Notes on Contemporary Indonesian Political Communication," Indonesia 16 (October 1973): 65.

50 Peter Tomasoa, Pergerakan Sedjarah Pemuda Indonesia (Jakarta, 1950).
} 
one of the demonstrators, but added that the physical difference between the demonstrators and the attackers was "insignificant." Contemporary witnesses observed that the attackers were well-trained, and that their long hair appeared to be wigs. The Berlan boys involved later defended themselves in court by claiming that they mistook the demonstrators for rivals from Sartana, Casanova, or Siliwangi.51 Thus army brats who happened to be gangsters pass as long-haired rowdy youths picking fights with "crossboys" who turn out to be demonstrators yet resemble rivals from another barracks. In this confused failure of recognition, the transformation of gangsters into youth and youth into delinquents was effected.

The "clash" between these "rival youths" precipitated efforts to regularize and authorize youth, refiguring opposition as wild elements and subordinating gangsters (already informally linked to the army through their parents or other patrons) to the intelligence apparatus by "dissolving them." On January 15, 1972, Kopkamtib Commander General Soemitro issued an instruction dissolving and outlawing "groups and gangs of teen-youths" with the following considerations:

1) Recently especially in the large cities there have emerged groups of teenyouths calling themselves, inter alia, BERENLAAN GANG, GANG IC STRAAT, GANG SARTANA and so forth whose activities tend toward criminal acts, inter alia, fighting/battery/murder/rape/extortion/illegal Narcotic Drug use and robbery, and improper behavior.

2) Other than that it has been proven ... that these GANGS were used by the Anti-"Beautiful Indonesia"-in-Miniature Movements to incite riots, which resulted in many people wounded in inter-GANG fighting and then these victims were used as martyrs by the Anti-"Beautiful Indonesia"-in-Miniature Movements to stir up emotions and mass movements.

3) With this in mind, the growth and development of the lives of our teen-youths must be saved. 52

Although Tien mobilized the Berlan gang to attack opponents, 53 the instruction faults the demonstrators for organizing their own attack with the intent of making themselves into martyrs, enunciating a procedure later to become standard: speak of your own infiltrators as your target's agitators. The instruction also reveals that the language of juvenility (here: pemuda-remaja) had yet to settle on a standard form. At the time, youth occupied a liminal space of semi-remaja, semi-pemuda.

"Dissolution" of the gangs proceeded apace with the formation of various units to tackle the newly-defined youth problem. The approach tended to focus on turning youth on the one hand into teens, and on the other into "natural human resources" (SDM), including resources available as-one might say-"mine-able" assistants of the authorities. Not to be outshone by Kopkamtib, BAKIN expanded BAKOLAK INPRES $6 / 1971$, a body established to control smuggling, creating a sub-unit known as

\footnotetext{
51 Tempo, January 1, 1972; Kompas, December 24, 1971-January 5, 1972; Kompas, May 9, 1972. Conversation with Asmara Nababan, July 28, 1998.

52 BAPPENKAR JATIM, "Perang Total Melawan Narkotika demi Keselamatan Generasi Remaja Kita Sebagai Harapan Cita-Cita Bangsa," East Java, 1972.

53 Several sources confirm that Tien Suharto ordered the attack.
} 
BAPPENKAR, or Executive Body to Tackle Narcotics and Child-Teen Delinquency. ${ }^{54}$ In February 1972, a solemn ceremony took place at the Jakarta Provincial Council, where some two thousand pemuda surrendered their "gang logos" and other parts of their "gang outfits" to District Police Chief Widodo, and were given a chance to speak their minds. A representative of one gang blamed their parents: " . . we are like newborn babies and are hurting because our parents don't give us milk." Another "demanded" that they be given jobs. By May 1973, the BAKIN sub-team finally obliged, assembling the "former" heads of gangs for industrial training as mechanics, establishing a pattern of access to "preman" followed by other army commanders, including for example Prabowo Subianto, who in the 1990 s established motor shops in East Timor as a source of livelihood for his network of informers. Taking their cue or their orders from Soemitro, local commanders throughout Indonesia began to increase their access to gangs by establishing various Teen Clubs, with an emphasis on sports. The Knighthood Teen Association (IREKA) formed in the Berlan complex played volleyball and sponsored dances. In Ujung Pandang, the local Kopkamtib commander unified a number of local gangs into a Nature Lovers' Teen Clubs Cooperative Body, organizing hikes, motor racing, and publishing a newsletter called "New Spirit" (Semangat Baru), and thus necessarily channeling funds to the teenified gangsters. This period also witnessed the consolidation and expansion of Special Anti-Bandit Teams (TEKAB) under the Jakarta district police, which recruited members of gangs including Sartana and Legos to "secure their individual kampungs."55

The effort to make the better-educated and more formally organized youth (such as those belonging to the extra-campus student organizations) the object of family planning (literally) can also be seen as a consequence of the Mini affair. In March 1972, Ali Moertopo intervened in a dispute between extra-campus youth organizations over the right to control World Assembly of Youth funds meant for family planning, securing navy Captain Abdul Gafur a position on the National Youth Committee for the Family Planning Program. From this embryo, KNPI (Indonesian National Youth Council) was born when it declared in July 1973 the right to represent Indonesian youth in all international forums. Signatories of this "Youth Declaration" included Pemuda Pancasila chair ML Tobing, and David Napitupulu, erstwhile Presidium Chair of KAMI and representative of Pancasila Students (Mapancas), another IPKI ounderbouw and therefore associated with Pemuda Pancasila. Though met with significant resistance, KNPI eventually became the "sole forum" for youth organizations in Indonesia, requiring that all youth organizations, subsequently called OKP (Youth Social Organizations), belong to it. KNPI pioneered a new mode of youth action fitting for the New pemuda, turning demonstrations into delegations supporting government programs or criticizing easy foreign targets. ${ }^{56}$ Acting as the government's

\footnotetext{
54 BAPPENKAR, Badan Pelaksana Penanggulangan Narkotika \& Kenakalan Anak-Anak Remaja. Its first publication, "Total War Against Narcotics for the Salvation of Our Teen Generation as the Hope and Dream of Our Nation," was, in addition to an outline of the Juvenile Delinquency problem, a frame for the dissemination of Soemitro's instruction.

55 See Tempo, January 15, 1972, February 17, 1973, July 14, 1973, and January 26, 1972.

56 Tempo, November 2, 1974. In reaction to a University of Indonesia petition criticizing development strategy, in December 1973, KNPI led a "delegation" to the National Planning Board in order not to criticize, but to relay "the essentials of our thoughts for the perfection of the second five-year plan." Tempo, December 15, 1973. In 1975, KNPI protested the burning of the Indonesian flag in Holland by "remnants"
} 
"partner," in close coordination with a new Ministry of Youth and Sports in which Gafur became the first minister, KNPI helped to make "building-up [pembinaan] the young generation" the defining approach to youth during the New Order.

\section{He Who Shouts the Loudest: The Rise and Reign of Pemuda Pancasila}

Pemuda Pancasila's genius was in recognizing the opportunity to enact the "role of pemuda" as it became more clearly defined. If it could defend the nation against foreign and internal enemies and support the government's efforts in various fields, it could create the space for itself not only to "participate in the development process," but also to guarantee that its other activities would remain relatively undisturbed. Youth represented a vast and relatively untapped "potential" (potensi), and as long as the majority could never be incorporated into the formal economy, a successful youth organization could manage marginal urban youth, providing members access to the formal labor market and the local administration when appropriate, and organizing them to lend some degree of order and "protection" to the streets when not. It is no coincidence that this strategy resembles the pattern of labor control in informal labor markets that gives rise to semi-criminal "underworlds" in other locations and periods. ${ }^{57}$ However, Pemuda Pancasila's novelty rested in the expansion of this labor principle to include employment in political projects in the context of a new nationalism centered around the personal requirements of a single, national (president) boss.

The re-emergence of Pemuda Pancasila under the leadership of Yapto Soerjosoemarno beginning in 1980 took place in an environment where sporadic efforts to organize the urban "underworld" were being met with limited success. Perhaps in an effort to make local bosses and their followers visible and (financially) responsible to the authorities, groups of so-called "recidivists" were encouraged to consolidate themselves into formal organizations. The most prominent of such organizations, Prems, founded in 1979 (some say with the patronage of Admiral Sudomo), was organized into departments, including a legal aid division, and boasted fifty thousand members by the time it was broken up during the Petrus killings in 1983. Perhaps one of the failings of Prems was its public image as a purely (ex-)criminal association. Although Prems denied that the name was an abbreviation for "Aware Preman" (Preman Sadar), it made no attempt to conceal the fact that its members were ex-cons and that its main function was to give them work, mainly in the security business. ${ }^{58}$

of the RMS, the South Moluccan Republic succession movement. A week after the East Timor invasion, KNPI protested against Australia for its failure to perceive the matter in the Indonesian way. Kompas, January 15, 1975, and December 16, 1975.

57 For a good description of this in late colonial Batavia, see Robert Cribb, Gangsters and Revolutionaries: The Jakarta People's Militia and the Indonesian Revolution 1945-1949 (Honolulu: University of Hawaii Press, 1991).

58 In a letter to the editor in Kompas on February 17, 1982, Prems clarified that it was founded on November 10, 1979, as Yayasan Proyek Rehabilitasi Ex Naripidana Menuju Sejahtera (Project Rehabilitation Ex-Cons Aiming for Prosperity Foundation), abbreviated Yayasan Prems \& Associates. Since the Jakarta District Police Chief had objected to the use of the term "Ex-Con," on August 31, 1981 it changed its name to Yayasan Proyek Rehabilitasi Material dan Spiritual (Project Material and Spiritual Rehabilitation Foundation), or Yayasan Prems. Despite this correction, in popular parlance the tag Preman 
Various local groups such as Greater Bandung Youngsters which, like Pemuda Pancasila, claimed to guide youngsters so they wouldn't get involved in criminal acts yet in practice extracted money from "donators," did not survive long even though they had the "blessing of the authorities." Their strong sense of local identity (Greater Bandung Youngsters had a flag with the name of a Bandung street below a skull and crossbones) obstructed their chances for the kind of national recognition Pemuda Pancasila was able to gain. 59

Pemuda Pancasila's competition was not only organized ex-cons or local toughs, but also youth groups supporting Golkar, although the lines between the two, as I've been arguing, are indistinct. Its rivalry with Golkar's youth wing, AMPI (Angkatan Muda Pembaharuan Indonesia, Indonesian Renewal Young Generation), can be seen in the context of the effort to weaken Ali Moertopo's influence, which as one theory has it, was also a chief purpose of the Petrus killings. Although it is beyond the scope of this article to discuss the various interpretations of the Petrus killings, it is widely assumed that Suharto feared the ambitions of Ali Moertopo, especially his power-base in the gali, and that Benny Moerdani was under orders to wipe out his underworld forces. Many of them, especially though formal youth constellations such as AMS (Siliwangi Youths), had supported Golkar (through both campaigns and kidnapping and intimidation of opponents) during the 1982 elections. ${ }^{60}$

The "re-awakening" of Pemuda Pancasila followed on the heels of the 1978 formation of AMPI by Abdul Gafur, and hence Moertopo. Yapto Soerjosoemarno began his efforts to assume control of PP after January 1980 by setting up branches led by his personal friends and hunting partners in several provinces, precisely one year after David Napitupulu toured the regions consolidating AMPI's regional base. ${ }^{61}$ Gafur evidently saw Yapto as a challenge to AMPI, which he envisioned as unifying under the Golkar banner local youth groups in Moertopo's orbit such as AMS, a goal not fully accomplished until the completion of the 1982 elections. Bourchier argues that Pemuda Pancasila was granted a national franchise on the underworld after the elections and the Petrus operations, replacing Moertopo's network. ${ }^{62}$ However, the fact that Yapto became chair of PP well before Petrus (and was building his base more than two years before the 1982 elections) suggests a more protracted and complicated conflict over control of local "human resources." This conflict brings into focus the fact that in order to win influence during the New Order, one had to do so in the context of being Golkar's most enthusiastic defenders.

Sadar stuck, carrying with it an ambivalence between the state of being "aware" in the sense of repentance and the state of being "aware" of their own collective power as preman.

59 Greater Bandung Youngsters (Muda-Mudi Bandung Raya) tried to join KNPI, but were told that "there is no forum that can accommodate activities like ours." Tempo, September 3, 1983.

60 This view is supported by the circumstances of Prems leader Agus TGW's disappearance. He was kidnapped by armed men immediately after a meeting with leaders of AMS. Tempo, June 25 1983. For more on Ali Moertopo and Petrus, see for example David Bourchier, "Crime, Law, and State Authority in Indonesia," in State and Civil Society in Indonesia, ed. A. Budiman, Monash Papers on Southeast Asia (Clayton, Victoria: Monash University, 1990), pp. 193-195, which deals briefly with Pemuda Pancasila.

61 Warta Berita, April 7, 1980; Antara reports, January 1979.

62 Bourchier, "Crime, Law, and State Authority in Indonesia." 
Yapto's rise represented something of an internal coup against Pemuda Pancasila's then nominal leader, ML Tobing, who had cooperated closely with Gafur in the creation of KNPI. Yapto's imminent installment as chair of PP was strongly opposed by Gafur, on the grounds that Yapto himself was a "preman," but more probably for the reason that Yapto was not his preman. Just before the March 1981 PP congress, Yapto was brought up on gun possession charges in an effort to obstruct him, though he was quickly released. Tobing himself was detained for three days by Kodam Jaya (then under the command of Norman Sasono) in an effort to convince him to remain as chair, and only released after he signed a statement that Pemuda Pancasila's "aspirations" would be channeled to Golkar. Yapto, however, was determined, having already staged a convincing show of force by trucking in more than a thousand supporters from the regional branches he had established within the previous year. With Yapto's boys chanting things like "Viva Yapto!" during the congress, Yapto became sole candidate and then general chairman. Despite the presence of a thousand some anak buah (followers), however, it would be difficult to imagine that Yapto could have prevailed against the wishes of Gafur and Norman Sasono unless he had other support. Though Tobing was unaware of this at the time, he later concluded that the Suhartos needed their own "force". ${ }^{63}$ If the Suhartos saw a need for a preman base, Yapto was a likely candidate for the job. Yapto and Tien were distant cousins from Solo, and General Soerjosoemarno was also a personal friend of the family. His eagerness to settle conflicts violently may have been a factor; during the 1970s he had already established a reputation in Jakarta for machismo (kejagoan) as a leader of the Siliwangi boys.

Yet it would be too simple to conclude that the whole organization was set up by Suharto or that it was designed to become the "sole vehicle" for nationalizing gangs. The impetus to revive Pemuda Pancasila appears to have come not from Yapto but from PP old-timers in Medan led by Effendi Nasution, mentioned above. Effendi originally approached Yapto about holding a reunion in Jakarta, which eventually took place at Ancol in January 1980. There was a realization from the "grassroots" that to maximize profits, coordination, and, moreover, unimpeachable legality, was crucial. Siliwangi figures like Yapto and Tagor "had names, but they didn't have any papers." With legality, one could deal with the authorities. ${ }^{64}$ In the estimation of Pemuda Pancasila revivers, it took several years for PP to win the recognition and cooperation of the authorities. The turning point did not come until 1987, after a meeting with Assistant Chief of Social and Political Affairs (Asospol) General Harsudiyono Hartas, in which they convinced him that, as fellow sons of ABRI, their interests were compatible. After that, Pemuda Pancasila branches and the respective District Military Commands (Kodam) immediately "matched."

In its "struggle" for recognition, PP's affinity with the jago is revealed. On the one hand, inasmuch as the jago has been perceived as a defender of the wong cilik (the little guy), the effort to assert the existence (eksistensi) of the organization itself was a way to push for the interests of its expanding, largely disenfranchised, member base to be taken seriously. In practice, this entailed the distribution of local turf concessions. On the flip side, insofar as the jago has been seen as a figure on which authorities relied to

63 Based on several interviews.

64 Interview with Tagor Lumbanraja, July 18, 1998. 
maintain order in the face of potentially restless masses, PP's increasing success in expanding its influence promised that this threat could be curtailed. One of the most intriguing contradictions of Pemuda Pancasila is that it perceives itself as fighting for the welfare of its grassroots members, while at the same time maintaining a hierarchical organizational structure that mirrors the administrative units of the state, from the center down through to the RT level. Preman, inasmuch as they conceive of themselves as free men, also are said to value group solidarity. Within Pemuda Pancasila, group solidarity takes the form of obedience to the chain of command. Thus, Pemuda Pancasila can be seen to have successfully translated the logic of the jago into a formally "modern" organizational framework, organizing what might be said to be a nested system of jagos, where local bosses would be formally subordinate to the higher level "manager" of the branch or district office, yet expect to retain significant local autonomy over revenues.

The way in which Pemuda Pancasila made itself, to quote a popular phrase in the organization, "disliked but needed," also mirrors the style of the jago, though PP is strengthened by the bureaucratic reinforcement a formal organization can provide. The source of the jago's power, to paraphrase Blok on the Sicilian Mafia, comes through maintaining or encouraging social tensions that he is strategically placed to resolve. As Siliwangi Boys member cum former PP Secretary General Tagor indicated, it is only through an "incident" that a gang exists. In order to grow strong, it must create conflicts, to demonstrate its "existence." Indeed, the primary concern in the early years of PP's rebirth was the question of eksistensi, not questions of purpose. Pemuda Pancasila operationalized this logic beginning in the discos and, arguably, extending to the national scale. To gain control over night club security, for example, obnoxious drunkards would be sent in and would make their association with PP known. Thereafter, in response to a request from the owner, PP members would be sent in to insure that this would be the last such incident. When PP members busted up billiard parlors in Grogol in the name of "wiping out gambling," they at once punished owners for not paying enough protection money and made sure that their services would continue to be needed. Yapto boasted that local army commanders often ask for the assistance of Pemuda Pancasila in putting a stop to rioting in the regions, adding as an afterthought, with some delight, that "it is also our guys who are doing it." Yorrys Raweyai's post-reformasi support of independence for West Papua, then switch to support of local autonomy, can also be seen as conforming to this pattern. Within weeks, Yorrys was able to mobilize independence protests in Jayapura, then position himself as uniquely capable of convincing the "Irianese" to consider expanded autonomy instead. 65

Among the advantages the organization holds over the jago are ability to rotate personnel and the "impersonality" of the organization itself. The jago's

65 Interviews with Tagor, cited above; Yapto Soerjosoemarno, August 25, 1998; Anton Medan, March 18 21, 1998. On PP Grogol Petamburan's efforts to eradicate gambling, see for example Gatra, April 12, 1997. On Yorrys and Irian, see Panji Masyarakat, July 15, 1998; Sinar Pagi, September 2, 1998; Gatra, September 19, 1998. Since reformasi Yorrys has continued to position himself as a leading Irianese figure. Meanwhile, several Pemuda Pancasila leaders (especially provincial heads) have taken this "treasonous position" as reason to push for Yorrys's dismissal from the organization, although many of them admit that their actual motivation is to name a fall guy for Pemuda Pancasila's support for Suharto in May-and they realize this won't be Yapto. 
mischievousness is limited by the fact that his personality is unmistakable. If he makes a pest of himself in an effort to increase his own value, it is likely to be more in displays of his prowess rather than in wanton destruction. A jago is unable to disavow himself. However, the organization, inasmuch as it is itself embodied in law, is infinitely able to reorder or to disavow its constituent parts. With a tight enough structure of command, it is possible to bring in bodies from other regions or locales to create necessary incidents and then allow the local representatives to step in and save the day. Thus the perpetrators are unrecognized while the saviors are familiar. It can also insist on a division between the embodied organizational form and the fallible members who comprise it. The rational-legal organization itself thus takes on a divine, and ultimately vacant, form. ${ }^{66}$ Pemuda Pancasila has perfected this understanding of modernity by enacting by-laws and organizational regulations, to which all members must pledge their loyalty, which specify important matters such as terms of office, formal organizational structure, the measurements and layout of branch sign posts and letter seals, and the styles of uniforms appropriate for various functions. Local-level organization leaders implore members to understand the by-laws while lamenting that the majority of members have never read them. For their part, members frequently complain that they have "not yet received" the regulations, and perpetually wait for the branch offices to make photocopies available. It is as if a Platonic Form of the organization exists out there somewhere, always a step beyond perfect comprehension. Violators of this organizational form are nevertheless always oknum.

In Pemuda Pancasila's perfection of disavowal, it made itself needed by the regime. Its members are always available as oknum of an organization that is already, in terms of the state, an oknum. Pemuda Pancasila, as an organization, has no formal connection to Golkar, let alone the bureaucracy. It is an independent, idealistic, militant, youth organization oriented towards "prestige and concrete service" in accordance with Pancasila Morals. Marching in this direction, at each congress Pemuda Pancasila releases a "political statement" resolving to channel its political aspirations to a "socialpolitical force oriented toward constructive work and concrete service [karya dan kekaryaan], that is Golongan Karya."67 Thus any "excessive" actions in support of Pancasila and the 1945 Constitution, such as shouting down treasonous activists, are no more than the result of the organizations' idealistic zeal or the spontaneous actions of its members, and not the responsibility of any government officials or institutions. In turn, if sometimes enthusiasm gets too zealous and turns into "excesses" such as assault or ransacking, Pemuda Pancasila can "regret" the actions of a few irresponsible

\footnotetext{
66 Daniel Dhakidae commented in a not unrelated context, "ABRI is a very good thing, so holy, there has never been a flaw in the body of ABRI. If there is a flaw, it is certainly an oknum. Even if 99 percent of ABRI members committed crimes ... ABRI itself is holy." Oknum was originally a term in Indonesian Catholic theology referring to the three persons of God (the Father, the Son, and the Holy Spirit) in the Trinity. According to Dhakidae, this usage appeared in older Indonesian Catholic catechisms. Interview, July 10, 1998. This is the first definition of "oknum" in Kamus Besar Bahasa Indonesia. See Depdikbud, Kamus Besar Bahasa Indonesia (Jakarta: Balai Pustaka, 1988). On "oknum," see also note 9 above.

67 See Anggaran Dasar, article 2 and "Pemuda Pancasila Political Statement" in Hasil Keputusan Musyawarah Besar V, Pemuda Pancasila, or the report from any congress after 1981, as the language is nearly identical. Golkar must meet four conditions that are already part of Golkar's program to win the support of Pemuda Pancasila. Kekaryaan has been understood to include work beyond normal duties, such as a military officer assigned to a civilian post (Echols \& Shadily's Kamus Indonesia-Inggris). Thus it would include a "civilian" performing voluntary military duties as well.
} 
oknum. A third stage of disavowal is the non-recognition of membership based on the non-possession of a membership card. Since Pemuda Pancasila "attributes" are available for purchase to anyone on the open market, a troublemaker wearing their trademark orange and black striped camouflage $t$-shirt is not necessarily a member. ${ }^{68}$ This is doubly true for someone wearing "baju preman." Drawing on the state's identification of proof of citizenship and identity (to be in possession of one's KTP, the state-issued ID card, means to "have an identity"), one's PP-ship is not provable if one is caught in the act without a membership card. Thus local youths defending-the-state or wiping-out-gambling are not-necessarily-PP or already-dismissed-ex-PP, and PP in turn is not under the command of the ruling party, let alone the army, but only expresses its spontaneous support thereof.

This reputation suggests another way PP has been of service to the state. With such all-but unfulfillable requirements for proving PP's institutional involvement in these excesses of enforcement, Pemuda Pancasila has become the quintessential usual suspect, especially in a string of actions that took place immediately after President Suharto-with considerable fanfare-opened its sixth national congress in June 1996. Prodem activists routinely finger PP, even when repressive actions are spear-headed by other organizations such as FKPPI or involve the mobilization of hired "preman" (read: the desperate poor) off the streets. For instance, when a group of youths backed by the military raided Megawati Soekarnoputri's PDI (Indonesian Democratic Party) HQ in July 1996, many groups immediately suspected that those passing as supporters of Soerjadi, Megawati's government-installed rival, were chiefly Pemuda Pancasila members. This assumption, relayed through human rights groups from Jakarta to New York, was quickly adopted by several members of the US congress, who in a letter to the Indonesian Foreign Minister called PP a "paramilitary group which was the vanguard of the attack on the PDI offices" and demanded its dissolution. ${ }^{69}$ With PP taking the heat in this way, ABRI commanders are freer to coordinate such actions using manpower tapped from other sources, including "preman" from the various

\footnotetext{
68 For example, during the early May 1998 rioting in Deli Serdang on the outskirts of Medan, seventy looters wearing PP t-shirts were later publicly disavowed by PP North Sumatra officials, who insisted the $t$-shirts were distributed by a "big thief" bent on discrediting the organization and taking advantage of the situation. This announcement was made at a press conference given on November 9, 1998, in which they threatened to sue the government-established Joint Fact Finding Team (TGPF) for slander. TGPF's report on the May riots included a statement that: provocateurs are "generally difficult to recognize, although in a number of cases [provocation] was carried out by groups from youth organizations (for example in Medan the direct involvement of Pemuda Pancasila was discovered)." (TGPF, Executive Summary, Final Report, May 13-15, 1998 Incident, October 23, 1998).

69 Letter to Foreign Minister Ali Alatas, dated August 6, 1996, signed by Patrick J. Kennedy, Barney Frank, Christopher Smith, and Nita Lowey. Although a known PP member named Cornelis was identified by cons in Salemba prison during the raid on Megawati's PDI on July 27, 1996, credible evidence also points to involvement by poor residents of Kapuk, North Jakarta, who on several prior occasions were gathered by the army under the pretext of preparing for a parade or gotong royong, and then given cash and sent home. On the July 27, they found themselves wearing the Medan congress t-shirts and being ordered to attack PDI HQ. This suggests that raiders, pre-tested for obedience, were pulled from several locales. On Cornelis, see Tri Agus, "Bagaimana ABRI Menggunakan Preman: (Komandan Preman Penyerbu DPP PDI Itu Bernama Cornelis)," A pakabar-L, October 3, 1996. On Kapuk, see Adil, October 16-22, 1996. To confess to participation in the raid also became a profit-making venture for one preman, Bella Seno, who hoped to sue Soerjadi for payment. He lost in court. See "Political Gangsters" in Inside Indonesia, January-March 1998.
} 
military units themselves, as we have seen with a vengeance in Prabowo's mobilization of Kopassus and Kodam preman during the May 1998 rioting. ${ }^{70}$ This in turn has tended to undercut PP's necessity as an actual force, while shoring up its importance as a symbol.

In exchange for "concrete service," PP expects concrete concessions in order to fulfill its mission to "raise the welfare" of its members. Members expect to be allowed to control revenues generated in the informal economy, especially parking and the "management" of informal traders, management that includes the collection of money for the provision of such services as security, cleaning, electricity, and water. They expect to be compensated with transportation money for mobilizing masses for rallies and events in support of local and national officials. They expect the assistance of local officials in employing their boys (and sometimes girls) in district and village level offices. They also expect preferential access in channeling their members into other private and government positions. To facilitate this process, PP leaders have occupied positions controlling manpower. Yorrys has served as Jakarta head of the sole government-authorized workers' union SPSI, and Yapto served a period as "caretaker" of the Indonesian Manpower Service Association (IMSA, now APJATI), which coordinates labor export. Their control over security at night clubs, likewise, must be tolerated, and one way to accomplish this has been through Yorrys's position as head of the Jakarta Tourist Industry Association, which includes entertainment complexes.

Pemuda Pancasila's control over these sources of "welfare" have come under challenge by another "Youth Social Organization" (OKP), Pemuda Panca Marga (PPM). PPM is headed in Jakarta by Harianto Badjoeri, an official in the Tourism Office, who has the authority to license pubs and discos, one thing Yorrys cannot do. As the youth wing of the Veterans' League, PPM is also an undying supporter of Golkar and the army. In practice, PPM has not limited its membership to the children of veterans and has taken other "sympathizers" under its wing. Its position on the streets has been strengthened by figures such as Hercules, an East Timorese who made a name for himself as a private assistant of Prabowo Subianto in East Timor. Some of his followers were brought from Dili, promised jobs by Suharto's eldest daughter, Tutut, then left to fend for themselves in Jakarta. ${ }^{71} \mathrm{He}$ and his boys, through the timeworn method of making and quelling trouble, sometimes wearing their camouflage PPM jackets and sometimes not, had in recent years assumed control of Tanah Abang and parts of Kota. Hercules has also "outbid" Pemuda Pancasila for Jakarta contracts to organize activities in support of East Timorese integration, such as some of the counter-demonstrations staged outside embassies during the asylum bids. This trend has created a rift between Prabowo and Yapto which is expressed in the latter's stated resentment of the government in general. "The government is putting in these other guys [from PPM] who don't even know what they are doing. . . . The discos where PP

70 See for example Tajuk, September 3, 1998. Kodam Jaya has threatened to sue Tajuk for publishing this testimony of someone who heard the confession of one of the deployed Kopassus personnel.

71 An Asia Watch report details the role of Yayasan Tiara, a foundation controlled by Tutut, in recruiting and then abandoning East Timorese youth, in some cases forcing them to undergo military training at the Kopassus-run complex in Cijantung, West Java. See Asia Watch, "Deception And Harassment Of East Timorese Workers," May 15, 1992. According to one East Timorese living in Jakarta, some of these people became preman in Blok $\mathrm{M}$ and Tanah Abang. Some of the latter group joined forces with Hercules, while others became his rivals. Confidential interview, April 1998. 
70 Loren Ryter

works as security are always safe and professional. The others are only collecting money and letting their friends drink for free."72

Fighting for national development (memperjuangkan pembangunan nasional) has, for the disenfranchised youth, come to mean dividing its blessings (pembagian rezeki) through seizing turf (perebutan lahan). If one considers that a large number of Pemuda Pancasila district and local managers run construction companies or are involved in demolition for developers, it is reasonable for them to join in the fight for this "building-up" (pembangunan) known as national development. Even explicitly political actions in its defense-such as counter-demonstrations, or an appearance in support of Suharto at the DPR in May-tend to be expressed in terms of "projects" and winning tenders. It is also illustrative to note that these material conditions have generated, in the New Order generally, but within Pemuda Pancasila particularly, their own idealist philosophies of materialism and the concrete. Both Yapto and Yorrys have published collections of short essays on such subjects as truth, human resources, national awakening, and the new spirit, which quote Socrates, Emerson, John F. Kennedy, and Fukuyama, among others. To achieve the goal of "reaching a better future," writes Yorrys, a "new spirit" (semangat baru) is required. What is this new spirit? "Spirit, in terms of an automobile, is the fuel which moves and animates the working mechanism of the car. Without fuel, the car can't do anything, at most it can be pushed." Spirit will drive you, in your private vehicle, to the prosperous future. Along the road, however, the highest value is to fill one's stomach-alias to work-ini yang kongkrit, this is what is concrete. ${ }^{73}$ Whatever else might be said about it, for many thousands of youths over the past decades, this philosophy worked. Given such prospects for youth struggle, it is easy to see how, to turn a phrase, the only way to be a spirited, patriotic pemuda during the New Order was to be a preman.

\section{Quo Vadis, Pancasila Youth?}

In the days after Suharto's resignation, Pemuda Pancasila had reason to worry that their late appearance at the DPR (in which at minimum they criticized Harmoko for speaking out of turn in calling on Suharto to resign) would damage their position. ${ }^{74}$ There was even concern that their bases would be attacked. How did Pemuda Pancasila wind up being the last ones holding the fort, and what is likely to be their fate?

\footnotetext{
72 Several confidential interviews, and interview with Yapto, August 25, 1998.

73 Yorrys Raweyai Th, Catatan Seorang Aktivis (Jakarta: Shahnaz Swa Mandiri, 1994), p. 75; Yapto S. Soerjosoemarno, Percikan Pemikiran Yapto S. Soerjosoemarno (Jakarta: Shahnaz Swa Mandiri, 1993); "Ini Yang Kongkrit," Pancasila Abadi, August 1996.

74 As mentioned in the introduction, Pemuda Pancasila disavowed openly supporting Suharto as president at the DPR on May 19, 1998. They could not, however, deny that they were at the DPR to criticize Harmoko, the speaker of the DPR, who the day before had called on Suharto to take the wise course and resign. PP was echoing General Wiranto's announcement that Harmoko's statement was not constitutional, that he had spoken out of turn without the agreement of all parliamentary factions. Ironically, PP brought a banner repeating a pun regime critics had for years leveled against Harmoko when he was Minister of Information: Harmoko, Hari-Hari Omong Kosong, Harmoko Bullshits Daily.
} 
How one interprets their position depends on how one reads both PP's connections to Prabowo Subianto and Prabowo's game in relation to his father-in-law more broadly. For reasons suggested above, and for other reasons having to do with personal differences between Yapto and Prabowo, one can assume that by May 1998 Prabowo's reliance on Pemuda Pancasila as a source of his preman was minimal. In fact, if one reads the rise of Pemuda Pancasila partially in light of the decline of Ali Moertopo's "zoo" (a term referring to his collection of underworld agents), it is tempting to see Pemuda Pancasila's current limbo in terms of Prabowo's menagerie. Over the past several years, Prabowo has been cultivating militant supporters both in and outside military units like Kopassus, focusing particularly on Islamic groups in West Java and on East Timorese and Irianese to whom he lent his patronage. One of the groups he cultivated most openly was Young Indonesian Knights (Satria Muda Indonesia), a pencak silat organization based in Banten for which he serves as Primary Advisor. He clearly played on anti-Chinese sentiments in various Islamic communities, particularly through sponsorship of the informal networks of Islamic congregations known as majelis taklim. One of the taklim pesantrèn for which Prabowo became a patron recruits repentant preman under the leadership of an ethnic Chinese former gangster from Medan cum Islamic proselytizer ( $\left.d a^{\prime} i\right)$ named Anton Medan. Despite later evasions, Anton Medan did in fact take to the streets during the May rioting, privately boasting to several people shortly after the event that he burned down the home of Liem Sioe Liong. ${ }^{75}$ The fact that he was briefly made into the leading scapegoat as the dalang (orchestrator) of the May rioting but later was quietly dropped as a suspect supports the idea that he has something to tell. ${ }^{76}$ Prabowo also could mobilize more professional support, including operatives from Kopassus and Kodam Jaya wearing basic black, or even uniforms from other units. ${ }^{77}$ By any estimation, he had considerable resources outside of Pemuda Pancasila upon which to draw.

This is not to assert that Pemuda Pancasila took no part in the rioting, but only that if its members did take part, it was for rather different objectives. Assuming that Prabowo mobilized instigators of the destruction on May 13-14, 1998, there are at least two hypotheses about his motives. One is that he was making a personal bid for power, at the expense of "dad" (and as Pangkostrad, commander of Kostrad, following in dad's footsteps). The other was that he went overboard in an effort to create the pretext for maintaining daddy-in-law in power, with a promotion to Pangab in mind as his bonus. Because of their closeness to Suharto's son Bambang Trihatmodjo and personal loyalty to the Suhartos, Pemuda Pancasila leaders would have cause not to support the former objective and to distrust the later objective. At any rate, they appear to have only realized very late what was about to go down. On the evening of May 13, the day after the Trisakti shootings and as fires were burning in several separate areas of Jakarta, Pemuda Pancasila held a press conference at KNPI. Their message was that

\footnotetext{
75 See Sinar, July 14, 1998.

${ }^{76}$ Most likely about the involvement of then Pangdam Sjafrie Sjamsudin. As an ethnic Chinese Muslim, Anton Medan appears to have been easily manipulated, and was called on to demonstrate his loyalty to Islam or himself become a target. This is the subject of another article, however. Anton was a rival of Yorrys in the gambling circles of Jakarta in the early 1980s. He bragged that he was driving a fancy sports car when Yorrys was driving around in a Honda Civic. Interview, March 18-21, 1998.

77 As one rumor had it, high police officials had complained that they were charged for a large number of uniforms they never ordered, which were shipped to East Timor.
} 
they supported reformasi, but that they understood this to mean "reformation" in all sectors except presidential succession. "I've never heard the students demand a replacement of national leadership," Yapto explained. "This isn't their main demand. Pure [murni] students aren't doing that." Yapto offered Pemuda Pancasila's services in supporting the students' struggle for reformation by "disciplining" the demonstrations so that they didn't turn to anarchy. Revealingly, he also offered to provide, if asked, PP's services in protecting "vital locations" such as companies, shops, or real estate, adding that PP operatives were highly professional. ${ }^{78}$ These statements suggest two things. First, Yapto was reading developments in terms of conflicts between students and Suharto rather than in terms of the larger power plays. Though it would be another several days before officials publicly jumped ship, scrambling to distance themselves from Suharto and climb aboard Reformasi, most players already assumed the end game, unwilling to comment one way or the other about Suharto, but actively preparing for his fall. Yapto understood the power plays mainly as challenges to Suharto rather than as developments that had already shot far past Suharto, and this made him a relic. Second, his offer of protection suggests that, even given the fact it was probably accompanied by a private agreement to riot, he had no conception of the scale of what was about to transpire. His offer was motivated by profit.

Events since May further indicate that contracts for Pemuda Pancasila in preman projects may be drying up, with the balance shifting in favor of ascendant Islamicoriented preman. This no doubt reflects the tensions within ABRI between what has been termed the Red \& White ABRI and the Green ABRI, or secular-nationalist versus Islamic factions within ABRI. The composition of the so-called Pam Swakarsa (roughly, Self-Security) "civilian" defenders of the November 1998 Special Session of Parliament (SI MPR) dramatically illustrates this division. On November 11, the first day of the session, several OKP (Youth Social Organizations), including Pemuda Pancasila, Pemuda Panca Marga, and FKPPI, showed up in uniform to secure the parliament building from student demonstrators, who were challenging the legitimacy of the session. However, they were vastly outnumbered by thousands of plainclothes (baju preman) "volunteers," many armed with bamboo spears, brought in from Tanjung Priok, Banten, and elsewhere. ${ }^{79}$ Shouting Islamic slogans, these groups were significantly more eager to physically confront the students. After the first day, Pemuda Pancasila and FKPPI withdrew their members, while Pemuda Panca Margawhich though still considered "Red \& White" is (in Jakarta, as explained above) more closely linked to Prabowo-stayed on. The Pam Swakarsa withdrew or were evacuated by the army only after physical challenges from students and the crowds led to fatalities; several of the Pam Swakarsa were beaten or hacked to death. I would

\footnotetext{
78 Notes, May 14, 1998.

79 Unlike their style for describing such actions before the resignation of Suharto, the mass media widely reported that these Pam Swakarsa were well-organized and promised payment. An internet source (Kabar dari Pijar, or $\mathrm{KdP}$ ) also revealed that the Indonesian Catering Entrepreneurs' Association (APJ) had been contracted to coordinate provisions for the Pam Swakarsa during the Special Session, but complained that many of their members were never paid. KdP advised APJI to pursue its complaint with Indonesian Committee for World Islamic Solidarity (KISDI) chief Ahmad Sumargono and leaders of the Star-Moon Party (Party Bulan Bintang), both of which are commonly considered to be connected to Prabowo. KdP Net, "PAM SWAKARSA mengemplang pengusaha catering Jakarta ratusan juta rupiah," November 21, 1998.
} 
suggest that despite its willingness to use violence, Pemuda Pancasila is not prepared to be on the defending side of a battle. During the New Order the main source of its strength was the visibility of a uniform that signified a united ABRI behind it. Yapto and company made the initial effort to return to time-worn patterns of backing-up the government's agenda with its Special Session. They withdrew, however, when they realized that their involvement not only posed a genuine risk, but stood to diminish their popularity and, consequently, their marketability.

Given Pemuda Pancasila's current tarnished reputation and indecisive position, one could predict at least two, not necessarily compatible, futures for the organization. In one future, the organization will get out of the political game and return to its basis in protection. This option seemed likely to anyone who witnessed the bleak mood among members at PP HQ in the immediate aftermath of the May riots. Much of Kota had been burned, and thus a main source of PP livelihood destroyed. A field operative called "the ranger" gave a thumbs up to the news that Liem Sioe Liong's house had been burned down, but he followed it with a sigh. "We have to admit, whatever else, that PP lives from the Chinese," he said returning to the phone, ringing up possible Chinese clients. In an alternate or perhaps parallel future, PP will enter the political scene in the context of reformasi, but it will do so by shedding its trademark orange and black camouflage outfit. Yapto notes that PP favors the district electoral system, because PP has members in villages throughout Indonesia, and the organization is sure to win one or two seats in parliament wherever it fields candidates. In this context, it is worth quoting a BAKIN sub-team report on preman: "Preman don't always wear tattoos ... During the last decade, preman used tattoos for group identity. However, because the authorities see tattoos as the mark of preman, they have tried to erase this mark. ... Preman these days are more clever than the generation of preman before them, and make themselves appear as if they weren't preman, so that their operations run more smoothly." 80 True to its roots in IPKI, Pemuda Pancasila would in this future become an integral part of the new democracy for a reformed Indonesia.

80 Mintarsih A. Latief, Strategi Penanggulangan Preman, Pengunaan Alkohol dan Zat Adiktif Lain (Jakarta: Yayasan Bersama and the World Health Organization, 1997), p. 15. Yayasan Bersama, which released the report, is under BAKOLAK INPRES 6/1971, mentioned above. 